\title{
Bedside balloon atrial septostomy on neonatal units
}

\author{
A C Martin, M L Rigby, D J Penny, A N Redington
}

Arch Dis Child Fetal Neonatal Ed 2003;88:F339-F340

Traditionally, neonates with transposition of the great arteries are immediately transferred to a cardiac centre. Travelling to the bedside to perform a balloon atrial septostomy and allowing the child to remain there for a few days before transfer is safe, effective, and a good use of medical resources.

$\mathrm{T}$ here is increasing recognition of the need for, and expansion of, regional and subregional neonatal intensive care facilities. However, specialist cardiac intensive care largely remains restricted to those centres that provide paediatric cardiac surgical facilities. Thus, although excellent general intensive care facilities may exist in the referring neonatal unit, transport of the neonate with critical heart disease usually remains a necessary part of the initial management of many of these patients.

One of the keystones to successful paediatric transport is adequate resuscitation and stabilisation before transfer, and this is particularly pertinent to the child with a major haemodynamic disturbance. However, even after resuscitation by the referring neonatologist and treatment with prostaglandin, some neonates with congenital heart disease will remain critically cyanosed and acidotic and at high risk during transfer. In many of these cases, urgent balloon atrial septostomy (BAS) is the only treatment that will relieve this critical cyanosis and restore adequate systemic oxygen delivery. It could be expected therefore that, in these critically ill neonates, urgent BAS at the referring hospital may reduce the risk associated with transfer to the specialist centre or indeed make such a transfer unnecessary. This report describes five neonates with transposition of the great arteries (TGA) in whom such an approach was used by our specialist cardiac retrieval team.

\section{PATIENTS AND METHODS}

Over a period of 26 months, five neonates with TGA had emergency BAS in their local neonatal intensive care unit. During this period, 54 neonates with a diagnosis of TGA were referred to the Royal Brompton Hospital, and 37 of these had a BAS before corrective surgery. Table 1 gives basic and diagnostic data for the five neonates. Our retrieval team consisted of a consultant paediatric cardiologist and a cardiac nurse. The intracardiac diagnosis in these patients was established using locally available ultrasound equipment. All patients had TGA and one also had a small ventricular septal defect.

If it was decided that BAS was necessary to resuscitate and stabilise the child, or may have avoided the need for transfer away from the local unit, then this was performed. The team brought all equipment necessary to perform this procedure. It was not considered appropriate if uncomplicated transfer could be achieved without septostomy or, for logistic reasons, transfer to the cardiac centre was felt to be more desirable. It is our policy to perform BAS under echocardiographic control only, and so a prerequisite to performing this in the referring unit was the availability of adequate two dimensional echocardiographic facilities. In all cases, the echocardiogram

Abbreviations: BAS, balloon atrial septostomy; TGA, transposition of the great arteries

\begin{tabular}{|c|c|c|c|c|c|c|c|c|c|}
\hline No & $\begin{array}{l}\text { Age } \\
\text { (days) }\end{array}$ & Sex & Weight $(\mathrm{kg})$ & Diagnosis & Before BAS & After BAS & $\begin{array}{l}\text { Day of } \\
\text { transfer }\end{array}$ & Operation & Outcome \\
\hline 1 & 1 & $\mathrm{~F}$ & 4.3 & TGA/IVS & $\begin{array}{l}\text { Sat } 40 \% \\
\text { pH } 7.1 \\
\text { Vent } \\
\text { Prostin }\end{array}$ & $\begin{array}{l}\text { Sat } 70 \% \\
\text { Extubated } \\
\text { Off prostin }\end{array}$ & D3 & $\begin{array}{l}\text { Switch } \\
\text { D14 }\end{array}$ & Well at 1 year \\
\hline 2 & 1 & $\mathrm{~F}$ & 4.4 & TGA/VSD & $\begin{array}{l}\text { Sat 70\% } \\
\text { Vent } \\
\text { Prostin }\end{array}$ & $\begin{array}{l}\text { Sat } 85 \% \\
\text { Extubated } \\
\text { Off Prostin }\end{array}$ & D7 & $\begin{array}{l}\text { Switch } \\
\text { Close VSD } \\
\text { D9 }\end{array}$ & $\begin{array}{l}\text { Well at } 7 \text { months } \\
\text { Mild RVOTO }\end{array}$ \\
\hline 3 & 1 & $\mathrm{~F}$ & 3.5 & TGA/IVS & $\begin{array}{l}\text { Sat } 75 \% \\
\text { Prostin }\end{array}$ & $\begin{array}{l}\text { Sat } 80 \% \\
\text { Off Prostin }\end{array}$ & D5 & $\begin{array}{l}\text { Switch } \\
\text { D14 }\end{array}$ & Well at 4 months \\
\hline 4 & 2 & M & 3.2 & TGA/IVS & $\begin{array}{l}\text { Sat } 18 \% \\
\text { Vent } \\
\text { Prostin }\end{array}$ & $\begin{array}{l}\text { Sat } 60 \% \\
\text { Extubated } \\
\text { Off Prostin }\end{array}$ & D5 & $\begin{array}{l}\text { Switch } \\
\text { D11 }\end{array}$ & Well at 2 months \\
\hline 5 & 2 & M & 3.7 & TGA/IVS & $\begin{array}{l}\text { Sat } 30 \% \\
\text { Vent } \\
\text { Prostin }\end{array}$ & $\begin{array}{l}\text { Sat } 50 \% \\
\text { Vent } \\
\text { Prostin }\end{array}$ & Died befo & ansfer & \\
\hline
\end{tabular}

BAS, Balloon atrial septostomy; TGA, transposition of the great arteries; IVS, intact ventricular septum; VSD, ventricular septal defect; Sat, transcutaneous oxygen saturation; Switch, arterial switch procedure; Vent, ventilated; RVOTO, right ventricular outflow tract obstruction. 
was performed by a member of the local paediatric team, who was given instructions about the desired probe position and echocardiographic image before the septostomy procedure.

\section{RESULTS}

The procedure was performed without complications in all cases. Table 1 gives the transcutaneous oxygen saturation after BAS and brief details of clinical progress. None of the patients required emergency transfer to the Royal Brompton Hospital. Four of the patients were in excellent condition after the BAS and were transferred for definitive surgery during the subsequent week. Patient 5, who by the time of arrival of the transport team was moribund with pulmonary haemorrhage and severe bilateral cerebral haemorrhages, also underwent successful BAS. However, it was considered to be more appropriate for further treatment be pursued in the local hospital, and sadly she died eight hours later.

\section{DISCUSSION}

Over 30 years after it was described by Rashkind and Miller, ${ }^{1}$ BAS remains the initial palliative intervention in most neonates with TGA. When originally described, the technique was performed using fluoroscopic screening during cardiac catheterisation..$^{2}$ In some cardiac units, including our own, it is now routinely performed at the bedside, in the cardiac intensive care unit, using cross sectional echocardiographic guidance. ${ }^{3}$ This has the advantages of avoiding further handling and delaying transfer to the cardiac catheterisation laboratory, and allows more precise imaging of the atrial septum and other cardiac structures.

We have described a logical extension of this technique, providing prompt resuscitation and stabilisation in the local neonatal intensive care unit. Successful BAS was performed in five patients. In three patients, it was considered that transfer without this would have been suboptimal, because of the coexistence of severe hypoxaemia and acidosis, despite treatment with prostaglandin. Two of these patients and two further patients had an excellent haemodynamic response and were able to stay at their local hospital, with their parents, before transfer for successful surgical treatment. In one patient, transfer before or after septostomy would have been extremely hazardous, and once the cardiac condition was palliated, all the facilities for continuing multisystem support were available locally.

Local BAS not only has these medical advantages, but also social and organisational ones. The social advantages of avoiding emergency transfer of the newborn child and mother to the specialist centre are obvious. There are also benefits to the specialist centre, where intensive care staffing, availability of beds, and specialised resources are all limited commodities which can be put to alternative use.

There are some potential disadvantages to the technique, however. Our transport team includes a consultant cardiologist or cardiac intensivist who is experienced in performing septostomy, but this level of experience is not universally available. Clearly, it can only be performed in units where the local facilities are adequate for care after successful BAS. Adequate equipment for cross sectional echocardiography is mandatory, but, interestingly, specialised echocardiographic assistance is not necessary, four out of the five procedures being performed with guidance from echocardiograms performed by the local paediatricians. A theoretical concern is the lack of surgical support should major cardiac complications occur after BAS. Historically, vascular and valvar damage have been described after BAS, ${ }^{4}$ but this is extremely rare now that the umbilical venous approach and echocardiographic monitoring is more often used.

In summary, bedside BAS in the local neonatal intensive care unit is a safe and effective palliation, avoiding the need for emergency transfer of infants with TGA. Although not universally applicable or necessary, it is an important additional resuscitative technique before, or even replacing the need for, emergency transfer of some neonates with congenital heart disease.

Authors' affiliations

A C Martin, M L Rigby, D J Penny, A N Redington, Royal Brompton Hospital, London, UK

Correspondence to: Dr Martin, University Department of Paediatrics, Princess Margaret Hospital for Children, Perth, Western Australia 6008; andrew.martin21@virgin.net

Accepted 23 September 2002

\section{REFERENCES}

1 Rashkind WJ, Miller WW. Creation of an atrial septal defect without thoracotomy JAMA 1966:196:991-2.

2 Ashfaq M, Houston AB, Gnanapragasam JP, et al. Balloon atrial septostomy under echocardiographic control: six years' experience and evaluation of practicability of cannulation via the umbilical vein. $\mathrm{Br}$ Heart J 1991;65:148-51.

3 Beitzke A, Stein Jl, Suppan C. Balloon atrial septostomy under two-dimensional echocardiographic control. Int J Cardiol $1991 ; 30: 33-42$

4 Booth P, Reddington AN, Shinebourne EA, et al. Early complications of interventional balloon catheterisation in infants and children. $\mathrm{Br}$ Heart $\mathrm{J}$ 1991;65:109-12. 